\title{
Evaluation of Mercury Contamination in Sediments from Santos - São Vicente Estuarine System, São Paulo State, Brazil
}

\author{
Marcos Antonio Hortellani, ${ }^{*, a}$, Jorge Eduardo Souza Sarkis ${ }^{a}$, Jarbas Bonetti ${ }^{b}$ \\ and Carla Bonetti ${ }^{b}$ \\ ${ }^{a}$ Laboratório de Caracterização Química, Instituto de Pesquisas Energéticas e Nucleares, IPEN-CNEN/SP, \\ Av. Lineu Prestes, 2242, 05508-900 São Paulo - SP, Brazil \\ ${ }^{b}$ Laboratório de Oceanografia Costeira, Universidade Federal de Santa Catarina (LOC-UFSC) Trindade \\ 88040-900 Florianópolis - SC, Brazil
}

\begin{abstract}
A distribuição da contaminação por mercúrio no sistema estuarino de Santos - São Vicente foi observada pela análise de 31 amostras de sedimentos coletadas desse sistema, incluindo as áreas de manguezais localizadas em zonas sob influência urbana, industrial e portuária. Os valores obtidos de $\mathrm{Hg}$ variaram de 0,04 a $1,19 \mu \mathrm{g} \mathrm{g}^{-1}$, sendo que cerca de $90 \%$ das amostras apresentaram concentrações superiores a $0,13 \mu \mathrm{g} \mathrm{g}^{-1}$, limite estabelecido pela legislação Canadense e adotado pela Companhia de Tecnologia e Saneamento Ambiental de São Paulo (CETESB), abaixo do qual não é observado efeito adverso na comunidade biológica. Entre estas, cerca de $35 \%$ possui teor de $\mathrm{Hg}>0,70 \mu \mathrm{g} \mathrm{g}^{-1}$, provável nível de ocorrência de efeito adverso à comunidade biológica, indicando um aumento devido às atividades industriais, portuárias e urbanas. A fim de se verificar a relação entre os parâmetros investigados, foi feita análise estatística empregando-se o software SPSS-10.0. Utilizou-se o teor de lama para normalizar o de $\mathrm{Hg}$, como recurso para detectar o grau de contaminação da região.
\end{abstract}

The distribution of mercury contamination in the Santos - São Vicente Estuarine System was observed through the analysis of 31 sediments samples collected from that system, including mangrove areas under urban, industrial and harbor influence zones. The range of values obtained was between 0.04 and $1.19 \mu \mathrm{g} \mathrm{g}^{-1}$. About $90 \%$ of samples presented $\mathrm{Hg}>0.13 \mu \mathrm{g} \mathrm{g}^{-1}$ levels, which is the limit established by Canadian legislation and adopted by the environmental control agency of São Paulo State - Brazil (CETESB), below which no adverse effect on the biological community has been observed. About $35 \%$ of these samples presented concentrations of $\mathrm{Hg}>0.70 \mu \mathrm{g} \mathrm{g}^{-1}$, the probable level of occurrence of adverse effect on the biological community. These results indicate an increase in the mercury levels caused by industrial, port and urban activities. A statistical study was carried out, using the SPSS-10.0 software, to verify relationships among all the investigated parameters. Normalization of mercury with mud content was used to detect the degree of mercury contamination in this area.

Keywords: mercury contamination, estuarine sediments, mangrove sediments, principal component analysis, normalization, Santos

\section{Introduction}

Sediments have a great capacity to accumulate pollutants in aquatic systems, even when these compounds present low concentrations in the waters, and therefore are regarded as one of the most representative environmental indicators of contamination, ${ }^{1}$ and can be used to map, trace and monitor anthropogenic sources of contamination and/or anomalies caused by geochemical natural processes. Many authors have studied mercury contamination in surface sediments of

*e-mail: mahortel@ipen.br sheltered environments, like estuaries, lagoons and bays. ${ }^{2,3,4}$ In those studies mercury contamination due to anthropogenic activities was observed. Two of these identified sources were: chloro-alkali factories, in which mercury cathodes were used for chlorine production and factories which processed imported ore containing traces of mercury.

It is known that the concentration of a contaminant in sediment tends to increase when particle sizes decrease because of enlargement of the surface area per unit. Therefore, an estimation of contaminant immobilization requires information about the grain size distribution and relationship between particle size, mineralogical differences and 
concentration of the contaminant in the sediment. ${ }^{5}$ Normalization is a common approach to compensate for anomalous metal concentrations in sediments and soils caused by grain size and mineralogical differences. ${ }^{6}$ In aquatic ecosystems, inorganic mercury enters a complex cycle in which it can be methylated in water and/or in sediments producing methylmercury, the most toxic form of $\mathrm{Hg}$. Methylmercury level in sediments is controlled by competing and simultaneous methylation and demethylation reactions. ${ }^{78}$ Usually methylmercury represents $1.5 \%$ of the total mercury present in sediments. ${ }^{8}$ This organic-metallic compound present in sediments can be released by diffusion or resuspension, and upon entering the food chain allows an effective biomagnification in aquatic biota. ${ }^{9} 10$ Thus, the ingestion of fish is an important pathway to mercury intake by man. ${ }^{11}$ Usually methylmercury represents more than $85 \%$ of the total mercury present in fish. ${ }^{12}$

The present research aims to study mercury distribution in the Santos - São Vicente Estuarine System. The range of mercury concentration was assessed to identify the most critical areas and the respective sources of mercury. For a better delineation of the dispersal patterns and preferential accumulation of this metal, the effect of grain size, total organic carbon and nitrogen in the sediments were also investigated. The purpose of this research is to contribute to the environmental knowledge of the area and to create aids to the elaboration of effective control plans.

\section{Environmental aspects of the study area}

This research was developed in the Santos - São Vicente estuarine area on the Southeast of São Paulo State, Brazil, in a coastal metropolitan region called Baixada Santista, with a permanent population of over $1,200,000$ and an estimated fluctuating population of 780,000 . This estuarine system comprises an intricate pattern of tidal channels and small rivers coming from the adjoining Pre-Cambrian slopes, and by two major estuaries (the Santos estuary and the São Vicente estuary, which intercommunicate in the upper region of the system (Figure 1, Figure 2 and Figure 3). The system is influenced by semi-diurnal tidal fluxes that present an average amplitude of $0.27 \mathrm{~m}$ in neap tide and $1.23 \mathrm{~m}$ of average spring tidal range. ${ }^{13}$ The Santos Estuary (located at the Eastern outlet) is distinguished by having the largest harbor in Latin America, carrying out an important role in the national economic scenario. Navigation in this estuary is guaranteed by periodic dredging along its principal axis, which maintains a depth of more than $10 \mathrm{~m}$. Beyond its natural complexity, the area also presents high vulnerability to the human

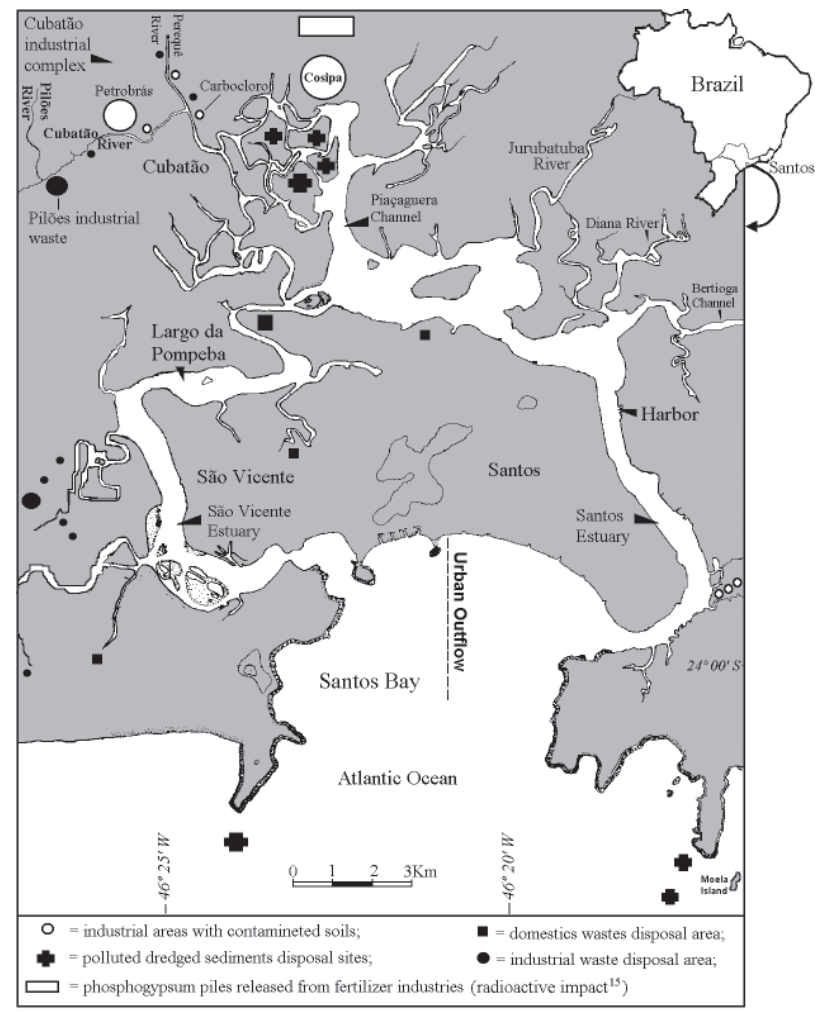

Figure 1. Localization of the polluted solid wastes disposal, in 1999, adapted from CETESB. ${ }^{14}$

impact caused by industrial activities, urban sewage and polluted solid wastes disposal (Figure 1). ${ }^{14}$ All these anthropogenic agents contribute directly or indirectly to the input of mercury to the area. The environmental characteristics of this site have been investigated for three decades and the high degree of pollution presented by its ecosystems has motivated serious preoccupation from government and society. As a result, the contamination of waters, sediment and marine organisms have been assessed sporadically by the Environmental Control Agency of the São Paulo State (CETESB).

Other authors have studied mercury contamination in the surface sediments of this area: Tommasi ${ }^{16}$ analyzed 50 samples collected in 1973 and the total mercury values ranged from 0.02 to $8.20 \mu \mathrm{g} \mathrm{g}^{-1}$; CETESB-1981 ${ }^{17}$ analyzed 32 samples collected in 1979 and mercury values ranged from 0.02 to $1.79 \mu \mathrm{g} \mathrm{g}^{-1}$; CETESB-1990 ${ }^{18}$ analyzed 15 samples from the Cubatão River (Hg range: $<0.4-6.65 \mu \mathrm{g}$ $\mathrm{g}^{-1}$ ) and 4 samples from the Santos estuary (Hg range: $<0.4$ $-2.14 \mu \mathrm{g} \mathrm{g}^{-1}$ ) collected in 1989; Prósperi et al. ${ }^{19}$ analyzed 18 samples from the Cubatão River and the range of mercury values were $<0.04-0.20 \mu \mathrm{g} \mathrm{g}^{-1}$; CETESB-2001 ${ }^{14}$ analyzed 67 samples from the Cubatão River, Santos Bay, São Vicente estuary and Santos estuary collected in 1998 and the range of mercury values were $<0.005-0.97 \mu \mathrm{g} \mathrm{g}^{-1}$. 
CETESB has made some general efforts in the last two decades to control and reduce the pollutant loads released to the environment mainly by the Cubatão industrial nucleus.

Since the first control plan, started in 1982, when this region was considered one of the most polluted estuarine areas of the Brazilian coast, $89 \%$ of the industrial sources of pollution was controlled (from a total of 274 detected), including atmospheric and hydric emissions. ${ }^{13}$ These efforts have in fact resulted in an improvement of the environmental quality. Some crustaceans, fishes and birds have returned to the rivers, estuaries and mangroves, regions previously degraded by several chemical effluents. But high concentrations of pollutants can be still found in those areas, mainly in the sediments (in which remobilization or degradation takes much longer).

\section{Experimental}

\section{Sampling and preparation}

Sixteen surface estuarine sediment samples were collected in May 1996 from Santos and São Vicente estuaries, and were sampled by means of a Peterson grab released from an oceanographic research vessel. To avoid metal contamination from the walls of the grab only the inner and surface fraction part was further processed. In May 1997 another 15 surface sediment samples were acquired manually from the surface fraction $(0-2 \mathrm{~cm})$ of mangrove sites during low tide, using a plastic spatula. The positioning of 31 sediment sampling stations is indicated in Figures 2 and 3. Immediately after collection, samples were carried to the laboratory and stored at $-20^{\circ} \mathrm{C}$. Prior to the mercury and sedimentological analysis procedures, the samples were frozen dried for 48 hours and sieved through a $0.5 \mathrm{~mm}(500 \mu \mathrm{m})$ nylon mesh.

\section{Mercury determination}

For mercury determination, the samples (portion of less than $0.5 \mathrm{~mm}$ particle size) were ground to a particle size of $<80$ mesh. Sediment samples were digested using the procedure of Akagi: ${ }^{20}$ in a volumetric flask of $100 \mathrm{~mL}$ (for this specific use), $0.5 \mathrm{~g}$ were taken from the sample, and 4 $\mathrm{mL}$ of acqua regia, $1 \mathrm{~mL}$ of $\mathrm{HClO}_{4}$ and $1 \mathrm{~mL}$ of water were added. The mixture was heated for 30 minutes at $90{ }^{\circ} \mathrm{C}$ on a hot plate. After cooling, the sample was then filtered (Whatman $\mathrm{N}^{\circ} 41$ ) into volumetric flasks of $25 \mathrm{~mL}$, and the volume was made-up with $18 \Omega$ water (Milli-Q).

The mercury determination in samples of sediments was made by cold vapor generation using an Atomic Absorption Spectrophotometer Varian, model Spectr-

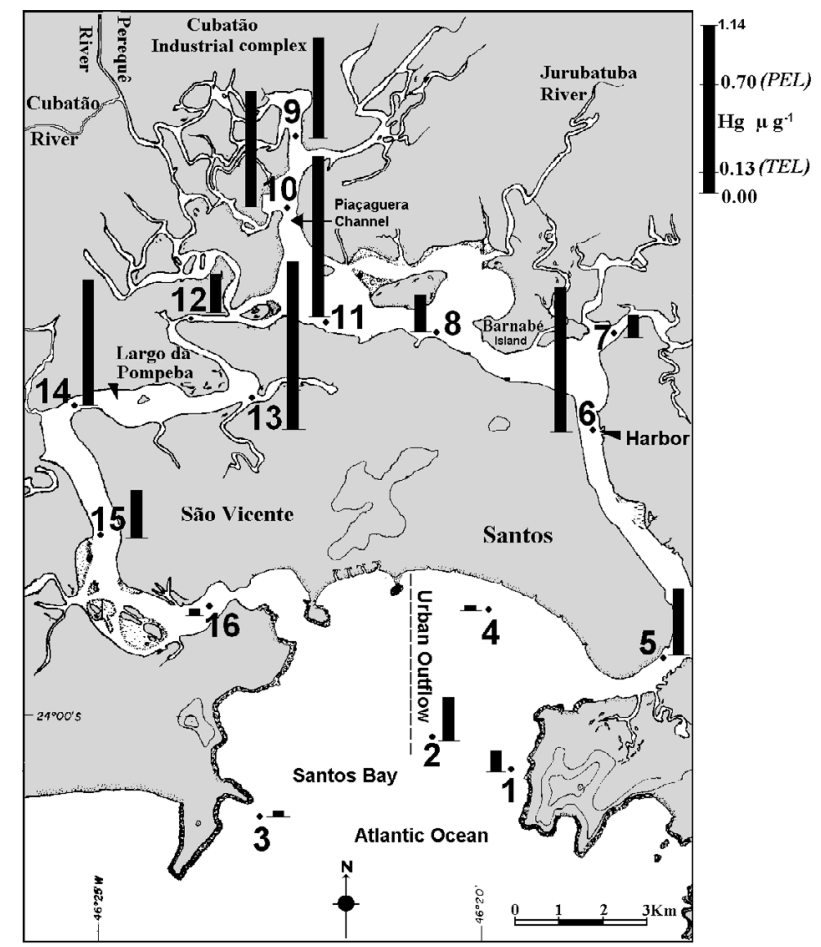

Figure 2. Localization of the sites where estuarine sediment were sampled and the concentration of mercury obtained (in a scale bar graphic).

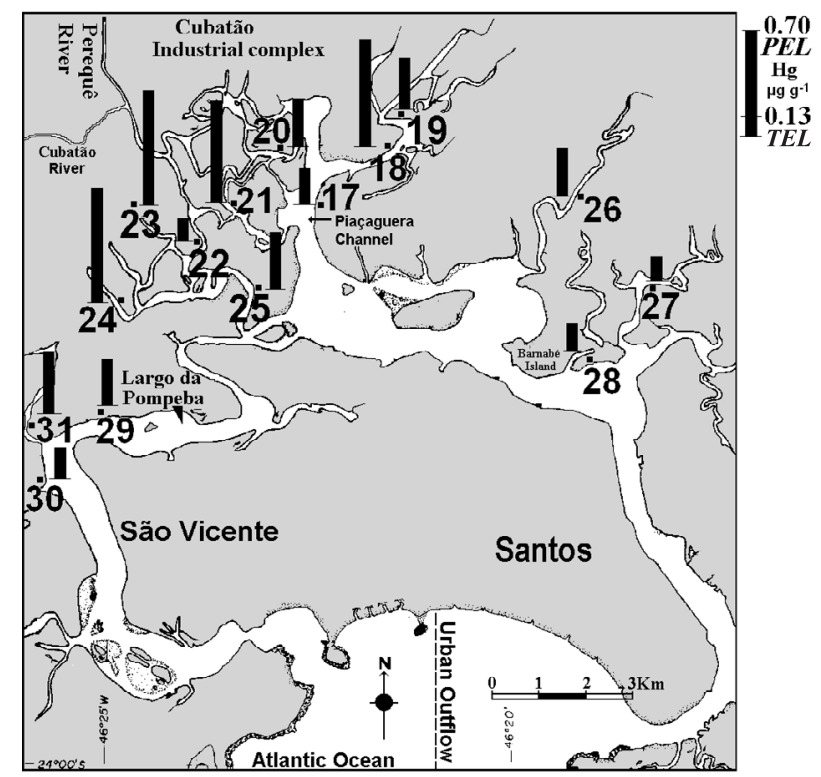

Figure 3. Localization of the sites where mangrove sediment were sampled and the concentration of mercury obtained (in a scale bar graphic).

AAS-220-FS, at $253.7 \mathrm{~nm}$. This spectrophotometer was coupled to a typical FIA (Flow Analysis Injection) manifold, ${ }^{21}$ with a manual injection valve that injects $500 \mu \mathrm{L}$ of digested sample at a flow of Milli-Q water (10 $\left.\mathrm{mL} \mathrm{min}^{-1}\right)$. The $\mathrm{Hg}^{2+}$ is reduced on line by $\mathrm{SnCl}_{2} 25 \%(\mathrm{~m} /$ v) in $\mathrm{HCl} 25 \%(\mathrm{v} / \mathrm{v})$ at a flow of $1 \mathrm{~mL} \mathrm{~min}^{-1}$. Argon was used as a carrier gas at a constant flow of $100 \mathrm{~mL} \mathrm{~min}^{-1}$. 
This technique has many significant advantages in comparison with the conventional batches procedure, as lower consumption of sample solutions and reagents, simplicity for mercury determination, high sensitivity and relative freedom from interference..$^{22}$

The peak area signals were measured and the mercury content of the samples was calculated against the mercury standard curves. All samples for this study were analyzed in three replicates. The validation of this method was performed by analyzing a certified reference sediment, Material 2704 - Buffalo River Sediment (Hg certified content: $1.47 \pm 0.07 \mu \mathrm{g} \mathrm{g}^{-1}$ ). The measured value was 1.48 $\pm 0.06 \mu \mathrm{g} \mathrm{g}^{-1}$, in agreement with the certified values. An accuracyrate of $0.7 \%$ was found; precision, expressed as a relative standard deviation (RSD), was $4.1 \%$, and $\mathrm{Z}$ score was calculated in agreement with INMETRO ${ }^{23}(|\mathrm{Z}|=0.22)$, an indicant of a satisfactory method. The detection limit for this method was also established in agreement with INMETRO, ${ }^{23}$ based in a mean of determinations of the seven blank preparations $(\overline{\mathrm{X}})$ plus three times the standard deviation determined by these seven preparation of the blanks $(\mathrm{LD}=\overline{\mathrm{X}}+3 s)$, and it was $0.47 \mu \mathrm{g} \mathrm{L^{-1 }}$. The determination limit $(\mathrm{LQ}=\overline{\mathrm{X}}+5 s)$ was $0.65 \mu \mathrm{g} \mathrm{\textrm {L } ^ { - 1 }}$. The final determination limit of this procedure, considering sample mass and dilutions of solutions was $0.03 \mu \mathrm{g} \mathrm{g}^{-1}$.

\section{Apparatus and reagents}

All reagents were of analytical grade with low levels of mercury. High purity water, of $18 \mathrm{M} \Omega \mathrm{cm}^{-1}$ resistivity was obtained using Milli-Q system. The Hg stock solution (1000 $\mathrm{mg} \mathrm{L}^{-1}$ ) was acquired by dissolving $\mathrm{HgO}$ (Johnson Matthey Chemicals Limited).

In the mercury determination, meticulous cleaning of the materials is essential. All glassware used was soaked for 24 hours in Extran 5\% (v/v), and rinsed with high purity water and $\mathrm{KMnO}_{4} 2 \%(\mathrm{~m} / \mathrm{v})$ with low levels of mercury. Next, it was rinsed with high purity water, soaked for 24 hour in $10 \%(\mathrm{v} / \mathrm{v}) \mathrm{HNO}_{3}$ and finally rinsed with high purity water for at least three times. After the analysis, the quartz cell and phases separator were rinsed with 5\% (v/v) Extran, high purity water, and were put in a $\mathrm{HNO}_{3}$ concentrate to be rendered clean by soaking until the next analysis.

\section{Sedimentological and other chemical analyses}

Simultaneously with the mercury determination, other analyses have been performed on sediment samples: grain size and chemical analyses (with particles of $<0.5 \mathrm{~mm}$ in size), like carbonate content and organic compounds (organic carbon $(\mathrm{C})$ and nitrogen $(\mathrm{N})$ total), to verify whether there was any influence of sedimentological characteristics on the mercury distribution. The grain sediment size was determined through the use of laser diffraction techniques (Malvern Series 2600). Although the methodological procedure adopted allowed the determination of 64 grain size classes, in this research the obtained particle size distribution was simplified and classified into six categories, following Flemming's proposition, ${ }^{24}$ based on mud $(<50$ $\mu \mathrm{m})$, and sand $(50-500 \mu \mathrm{m})$ contents. Therefore, the adopted sedimentological classes comprise: sand $(<5 \%$ mud), slightly muddy sand (5-25\% mud), muddy sand (25$50 \%$ mud ), sandy mud (50-75\% mud), slightly sandy mud (75-95\% mud) and mud (>95\% mud ).

The carbonate content was determined by the reaction of about $10 \mathrm{~g}$ of sediments (homogenized and dried at 60 $\left.{ }^{\circ} \mathrm{C}\right)$ with $\mathrm{HCl} 6 \mathrm{~mol} \mathrm{~L}^{-1}$. When the reaction was complete, the sample was filtered through previously weighed filter paper. The $\mathrm{HCl}$ excess was eliminated by a distilled water wash, and the paper was dried at $60{ }^{\circ} \mathrm{C}$. The carbonate content was determined by the difference between the initial and the final filter paper weight. ${ }^{25,26}$

The organic compounds in the sediments, represented by concentrations of total organic carbon (C) and nitrogen (N) were determined according to the procedure given by Mahiques. ${ }^{27}$ After pre-processing the samples with hydrochloric acid to eliminate the carbonates, the organic constituents present in the samples were analyzed using a LECO Multi-Analyzer CNS 2000. ${ }^{26}$

\section{Statistical analysis}

A correlation matrix between all the sedimentological and chemical parameters was carried out to recognize a previous relationships among $\mathrm{Hg}$ distribution and all the investigated parameters, in order to identify possible processes related to mercury deposition in sediments. Correlation analyses were performed on the data matrix using the Pearson Coefficient, according to $\mathrm{Zar}^{28}$ at $\alpha=$ 0.05 significance level.

The Principal Component Analysis (PCA) was applied to study different relationships between variables. The PCA was calculated by orthogonal linear combinations of the auto scaled variables, based on the maximum variance criterion, using correlation matrix.

\section{Normalization of mercury data}

Normalization is a common procedure used for detection and quantification of anomalous metal concentrations. Normalization procedures can be grouped into five main categories: ${ }^{29}$ (i) mechanical size 
normalization; (ii) extrapolation from regression curves; (iii) correction for inert mineral; (iv) chemical determination of the 'mobile' fraction only; and $(v)$ comparison for conservative elements - Enrichment Factor (EF).

The natural mercury concentration in sediment is determined not only by grain size distribution, but also fundamentally by the composition of minerals and secondary compounds. ${ }^{30}$ The decision for the best normalization approach for each one of the estuarine locales was made after careful examination of the prevailing local geological conditions ${ }^{30}$ and the anthropogenic input of contaminants. Recent results obtained by Abessa ${ }^{31}$ demonstrated that this estuarine region is polluted by metals, like $\mathrm{Fe}$ and $\mathrm{Al}$, caused by the industrial effluent of 23 large plants of Cubatão petrochemistry sector, ${ }^{32}$ therefore the application of a chemical normalization with a conservative element is impracticable. However, the statistical analysis shows a linear relationship between $\mathrm{Hg}$ concentration and the mud (silt + clay) content of the samples from this region. Therefore, in this work $\mathrm{Hg}$ data were normalized against mud content using two normalization techniques (extrapolation from regression curve and Enrichment Factor).

\section{Results and Discussion}

\section{Mercury determination}

Mercury concentrations in the studied area varied between 0.04 and $1.19 \mu \mathrm{g} \mathrm{g}^{-1}$ (Table 1). Threshold Effect Level (TEL) is the limit considered by the Canadian legislation, ${ }^{33}$ and adopted by CETESB, ${ }^{14}$ below which no adverse effects on the biological community are observed, and PEL (Probable Effect Level) is the probable level where an occurrence of adverse effects in the biological community happens. For mercury concentration in sediments, TEL is $0.13 \mu \mathrm{g} \mathrm{g}^{-1}$ and PEL is $0.70 \mu \mathrm{g} \mathrm{g}^{-1}$. Only three stations, two located in the Santos Bay (3 and 4) and one (16) in the São Vicente estuary close to the Santos Bay, presented mercury levels under 0.13 $\mu \mathrm{g} \mathrm{g}^{-1}$. About $60 \%$ of investigated areas ( 7 sediments of the estuary and 11 of the mangrove) presented mercury levels above $0.13 \mu \mathrm{g} \mathrm{g}^{-1}$ and under $0.70 \mu \mathrm{g} \mathrm{g}^{-1}$.

In six stations in the estuarine channels (Figure 2) and four in the mangrove (Figure 3), contaminations by $\mathrm{Hg}$ above $0.70 \mu \mathrm{g} \mathrm{g}^{-1}$ were found. The more critical samples were in stations 9, 10 and 11 in the Piaçaguera channel

Table 1. Concentration $\left(\mu \mathrm{g} \mathrm{g}^{-1}\right)$ of mercury and sedimentological features of the samples from Santos - São Vicente estuarine system

\begin{tabular}{|c|c|c|c|c|c|c|c|c|c|}
\hline & Station & $\begin{array}{c}\text { Water depth at } \\
\text { sampling site }(\mathrm{m})\end{array}$ & $\begin{array}{c}{[\mathrm{Hg}] \pm \mathrm{SD}} \\
\left(\mu \mathrm{g} \mathrm{g}^{-1}\right)\end{array}$ & $\operatorname{Mud}(\%)$ & Sand $(\%)$ & $\mathrm{CaCO}_{3}(\%)$ & $\mathrm{C}(\%)$ & $\mathrm{N}(\%)$ & $\mathrm{C} / \mathrm{N}$ ratio \\
\hline \multirow{16}{*}{ Estuary } & 1 & 10.0 & $0.15 \pm 0.01$ & 76.6 & 23.5 & 4.85 & 0.90 & 0.08 & 11 \\
\hline & 2 & 10.0 & $0.31 \pm 0.01$ & 81.1 & 18.9 & 2.98 & 1.38 & 0.15 & 9 \\
\hline & 3 & 9.2 & $0.04 \pm 0.01$ & 35.0 & 65.0 & 0.57 & 0.33 & 0.02 & 17 \\
\hline & 4 & 4.0 & $0.04 \pm 0.01$ & 17.3 & 82.7 & 1.21 & 0.32 & 0.04 & 8 \\
\hline & 5 & 4.0 & $0.47 \pm 0.01$ & 99.7 & 0.3 & 1.44 & 3.14 & 0.32 & 10 \\
\hline & 6 & 14.0 & $1.03 \pm 0.01$ & 99.9 & 0.1 & 3.03 & 2.85 & 0.22 & 13 \\
\hline & 7 & 4.0 & $0.16 \pm 0.01$ & 84.4 & 15.6 & 3.12 & 4.89 & 0.18 & 27 \\
\hline & 8 & 2.0 & $0.26 \pm 0.01$ & 52.7 & 47.2 & 1.01 & 0.70 & 0.04 & 17 \\
\hline & 9 & 4.0 & $0.71 \pm 0.02$ & 83.1 & 16.9 & 2.15 & 3.55 & 0.15 & 24 \\
\hline & 10 & 2.0 & $0.82 \pm 0.02$ & 81.6 & 18.4 & 2.30 & 3.36 & 0.19 & 18 \\
\hline & 11 & 2.0 & $1.14 \pm 0.03$ & 95.7 & 4.3 & 0.90 & 3.52 & 0.25 & 14 \\
\hline & 12 & 6.5 & $0.27 \pm 0.01$ & 41.6 & 58.4 & 1.91 & 0.89 & 0.04 & 22 \\
\hline & 13 & 0.9 & $1.19 \pm 0.05$ & 98.7 & 1.3 & 1.36 & 4.65 & 0.31 & 15 \\
\hline & 14 & 2.5 & $0.89 \pm 0.02$ & 98.5 & 1.5 & 5.72 & 4.72 & 0.34 & 14 \\
\hline & 15 & 2.5 & $0.34 \pm 0.03$ & 97.3 & 2.7 & 6.76 & 4.43 & 0.25 & 18 \\
\hline & 16 & 2.2 & $0.05 \pm 0.02$ & 7.6 & 92.4 & 2.03 & 0.31 & 0.01 & 31 \\
\hline \multirow{15}{*}{ Mangrove } & 17 & 0 & $0.24 \pm 0.01$ & 47.3 & 52.7 & 0.98 & 2.36 & 0.1 & 24 \\
\hline & 18 & 0 & $0.71 \pm 0.04$ & 93.0 & 7.0 & 2.43 & 6.97 & 0.35 & 20 \\
\hline & 19 & 0 & $0.34 \pm 0.02$ & 85.1 & 14.9 & 2.33 & 7.59 & 0.26 & 29 \\
\hline & 20 & 0 & $0.32 \pm 0.01$ & 85.4 & 14.6 & 1.43 & 3.66 & 0.12 & 31 \\
\hline & 21 & 0 & $0.67 \pm 0.04$ & 85.6 & 14.4 & 1.85 & 2.84 & 0.14 & 20 \\
\hline & 22 & 0 & $0.15 \pm 0.02$ & 49.8 & 50.2 & 1.05 & 2.72 & 0.13 & 21 \\
\hline & 23 & 0 & $0.76 \pm 0.01$ & 89.7 & 10.3 & 1.75 & 7.73 & 0.41 & 19 \\
\hline & 24 & 0 & $0.76 \pm 0.01$ & 67.4 & 32.6 & 2.11 & 11.6 & 0.5 & 23 \\
\hline & 25 & 0 & $0.38 \pm 0.01$ & 74.0 & 26.0 & 1.96 & 6.11 & 0.24 & 25 \\
\hline & 26 & 0 & $0.32 \pm 0.01$ & 92.0 & 8.0 & 2.00 & 9.28 & 0.53 & 18 \\
\hline & 27 & 0 & $0.16 \pm 0.04$ & 61.6 & 38.4 & 1.25 & 4.78 & 0.26 & 18 \\
\hline & 28 & 0 & $0.18 \pm 0.02$ & 51.5 & 48.5 & 2.00 & 9.22 & 0.38 & 24 \\
\hline & 29 & 0 & $0.31 \pm 0.01$ & 84.5 & 15.5 & 2.04 & 9.06 & 0.56 & 16 \\
\hline & 30 & 0 & $0.21 \pm 0.02$ & 83.3 & 16.8 & 2.97 & 12.8 & 0.64 & 20 \\
\hline & 31 & 0 & $0.41 \pm 0.04$ & 96.0 & 4.0 & 3.57 & 9.97 & 0.62 & 16 \\
\hline
\end{tabular}


(nearby industrial activities), in stations 13 and 14 in the São Vicente estuary, in station 6 in the Santos harbor and in four stations $(18,21,23$ and 24) in the mangrove area.

\section{Sedimentological analysis}

The sediments of Santos-São Vicente Estuarine System consist mainly of mud and slightly sandy mud. In the Santos Bay, two differentiated sedimentological zones are noticeable (Figure 4). The Eastern side is characterized by muddy sand, and the Western, adjacent to the mouth of the Santos Estuary, is covered by mud and slightly sandy mud.

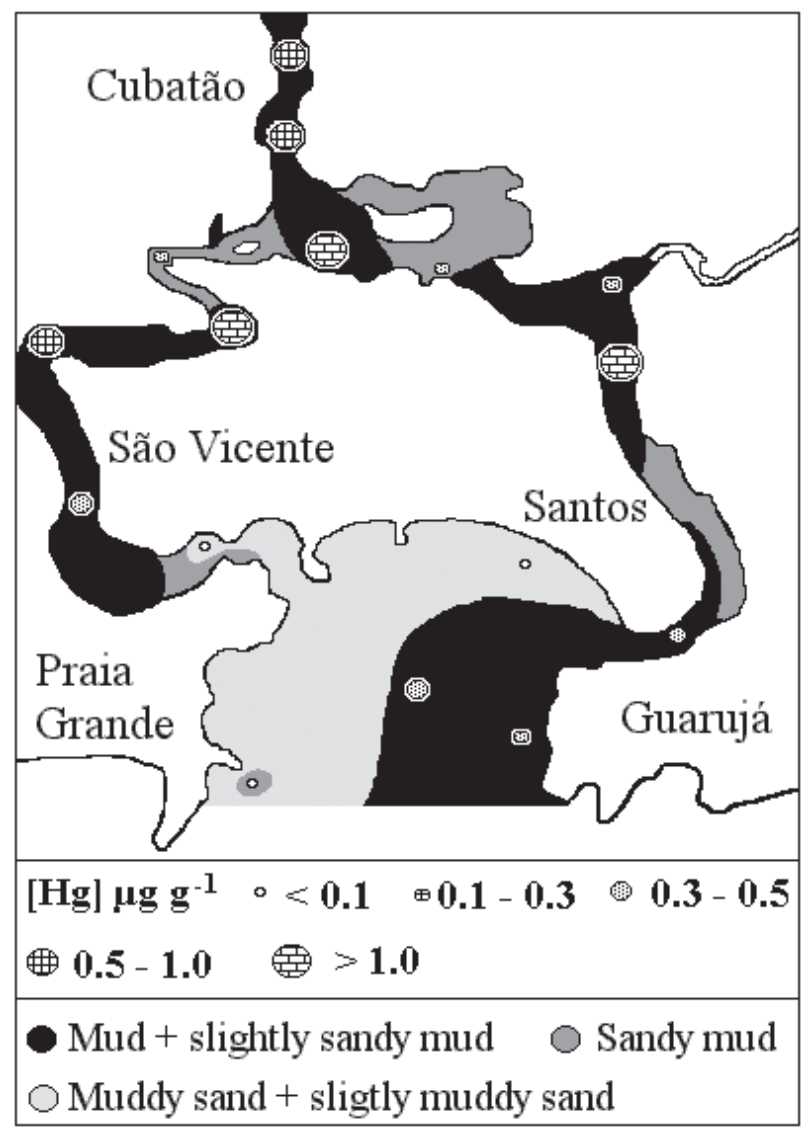

Figure 4. Comparative distribution of $\mathrm{Hg}$ concentrations and particle size classification of the marine sediments.

The predominant content of the sediment samples taken from the mangrove areas were slightly sandy mud or sandy mud. Only two samples contained $>50 \%$ of sand (stations 17 and 22). The concentration of organic carbon (C), nitrogen $(\mathrm{N})$ and carbonate content are presented in the Table 1. In a general way, these compounds increased towards the inner part of the system, presenting the highest concentrations in the most protected areas and near the fluvial inputs. In the estuarine samples, the contents of total organic carbon varied from 0.31 to $4.89 \%$. The São Vicente estuary presented mean concentrations higher than the Santos estuary, probably as a result of the heavier domestic sewage load that is released in its inner portion, and also due its limited hydrodynamic exchanges.

\section{Statistical analysis}

The best Pearson correlation obtained (Table 2) was between mercury concentration and the finer sediment fractions $($ mud $=$ Silt + Clay $)$. Samples with high contributions of mud fractions presented higher mercury concentrations $(r=0.64 ; \alpha=0.0001$, an indication of a highly significant correlation), while the sandy samples presented the lowest mercury concentrations. The organic compound content $(\mathrm{C}, \mathrm{N})$ in the sediments demonstrate a non-significant correlation with mercury distribution $(\alpha>0.05)$. However, a highly significant correlation between $\mathrm{C}$ and $\mathrm{N}(\mathrm{r}=0.93 ; \alpha=0.0001)$ was verified, suggesting that $\mathrm{C}$ and $\mathrm{N}$ have the same source. The origin of the organic matter present in this surface sediments was deduced based on the $\mathrm{C} / \mathrm{N}$ ratios (Table 1). Only three samples, two in the Santos Bay and one at the end of the harbor channel presented $\mathrm{C} / \mathrm{N}$ values between 4 and 10, indicating a non-vascular over a vascular plant input, according to Gomes, ${ }^{34}$ caused by planktonic and/ or microbial action on organic matter. A diminished marine influence toward the interior of the estuarine system was observed. $\mathrm{C} / \mathrm{N}$ values near and over 20 were found at the head of the system (the Piaçaguera channel), at the entrance to the Bertioga channel and in most of the mangrove samples, which denotes a greater contribution of terrestrial matter, ${ }^{27,35}$ or indicate a vascular plant input. ${ }^{34}$

The Principal Component Analysis in this study indicates that 8 variables can be represented by two new variables (Principal Components - PC). These PC explain $74.9 \%$ of the total variance in the original data set. In Figure 5 a scatter space plot of the scores in PC2 versus PC1 was reported. The plot in Figure 5a shows how the

Table 2. Correlation matrix of mud (silt + clay), sand (Medium + Fine + Very fine), organic carbon and nitrogen content, carbonate $\left(\mathrm{CaCO}_{3}\right)$ and mercury concentration in sediments samples $(\mathrm{n}=31)$

\begin{tabular}{lcccccc}
\hline & $\mathrm{Hg}$ & MUD & SAND & OC & N & \\
\hline Hg & 1 & & & & & \\
MUD & $0.64^{\mathrm{a}}$ & 1 & & & & \\
SAND & $-0.64^{\mathrm{a}}$ & $-1^{\mathrm{a}}$ & 1 & & & \\
$\mathbf{O C}$ & $0.14^{\mathrm{Ns}}$ & $0.43^{\mathrm{b}}$ & $-0.43^{\mathrm{b}}$ & 1 & & \\
$\mathbf{N}$ & $0.25^{\mathrm{Ns}}$ & $0.55^{\mathrm{b}}$ & $-0.55^{\mathrm{b}}$ & $0.93^{\mathrm{a}}$ & 1 & \\
$\mathbf{C a C O}_{3}$ & $0.07^{\mathrm{Ns}}$ & $0.42^{\mathrm{b}}$ & $-0.42^{\mathrm{b}}$ & $0.15^{\mathrm{Ns}}$ & $0.21^{\mathrm{Ns}}$ & 1 \\
\hline
\end{tabular}

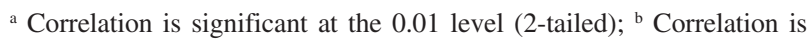
significant at the 0.05 level (2-tailed); Ns $=$ Non significant $(\mathrm{P}>0.05)$ 

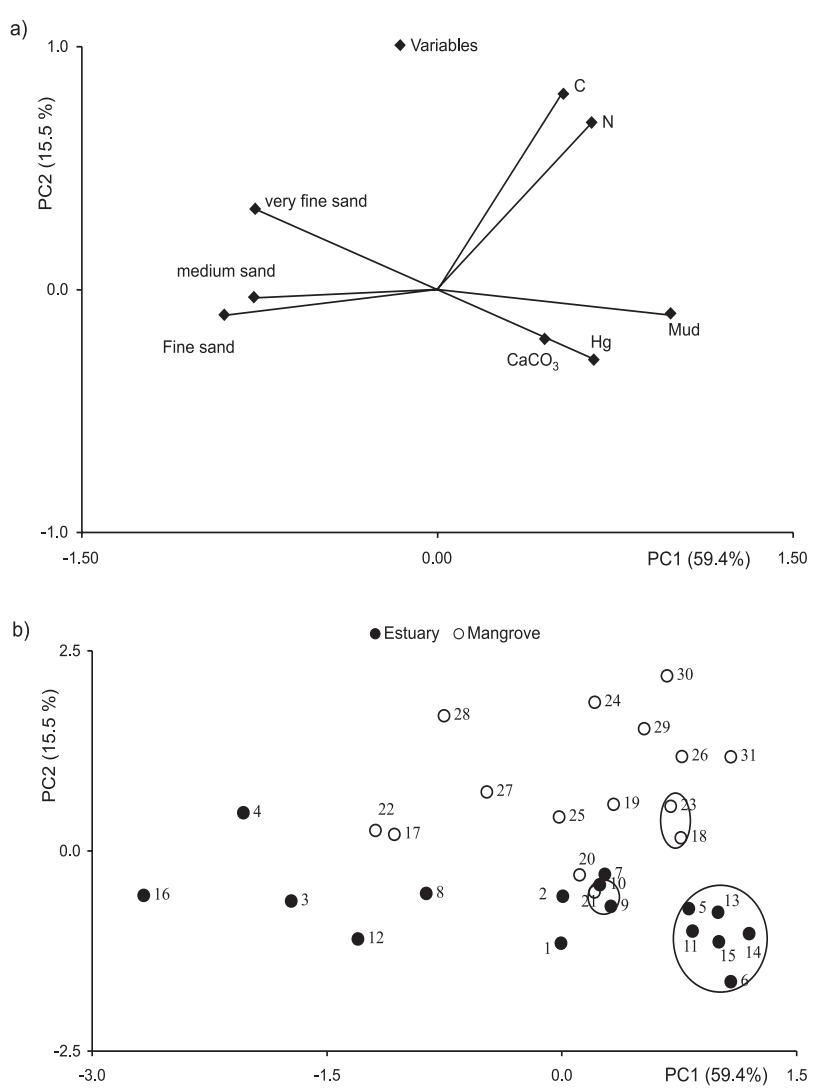

Figure 5. Scatter space plot of the first two Principal Components: (a) = variables and (b) = data of 31 stations.

Principal Component 1 was explained by the variables $[\mathrm{Hg}],[\mathrm{Mud}]$ and $\left[\mathrm{CaCO}_{3}\right]$ (they were grouped and had major correlation with PC1). The Principal Component 2 was explained by the $\mathrm{C}$ and $\mathrm{N}$ content.

The plot in Figure 5b shows how samples from the estuary were in one group (shaded circles), different from mangrove samples separated by the PC2. The plot shows that stations 5, 6, 11, 13, 14 and 15 made one group together, and this group is characterized by high $\mathrm{Hg}$ and mud concentrations.

\section{Normalization of mercury data}

Each normalization procedure has advantages and disadvantages, thus two normalization procedures were used to minimize the disadvantages of each one.

Extrapolation from the regression curve. The extrapolation from the regression curve was made by a scatter plot of $\mathrm{Hg}$ concentration versus mud content in the sediments (Figure 6), and possibly contaminated areas could be verified by the outlier values of a confidence band of $95 \%$ around the regression line. The sediments inside the $95 \%$ confidence band can be characterized as having natural mercury concentration, while all stations

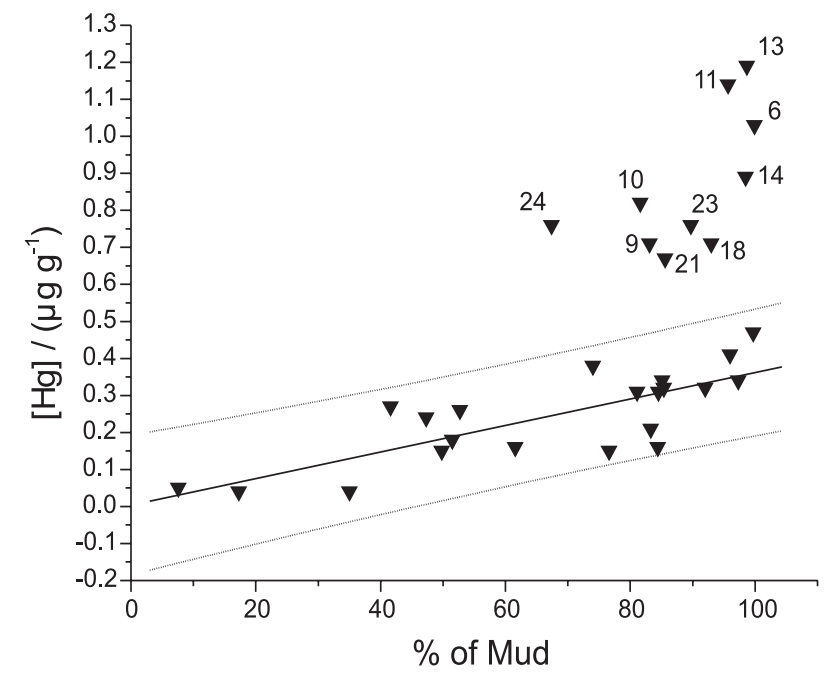

Figure 6. Scatter plot showing the relationships between mercury concentration $\left(\mu \mathrm{g} \mathrm{g}^{-1}\right)$ and Mud $(\%)$. The solid line represents the regression line $\left(\mathrm{R}^{2}=0.5958, \mathrm{n}=21\right)$; dashed lines define the $95 \%$ confidence band and represent $2 \mathrm{x}$ the standard error values.

above this band are characterized as contaminated sediments. ${ }^{30,36}$ The influence of anthropogenic factors on the mercury concentration could be verified in scatter plots because several points were projected above the 95\% confidence band. An impact caused by the effluents from industries was verified in the Piaçaguera Channel (stations 9, 10 and 11). Largo da Pombeba (stations 13 and 14) still shows indications of impact caused by effluents from industries. A possible source of contamination in the station 13 , were large quantities of urban waste deposited in a nearby area. In station 6 impact caused by port activities was indicated.

Enrichment Factor: The anthropogenic impact could be quantified by calculating the Enrichment Factor (EF) from the following equation: $([\mathrm{Hg}] / \mathrm{mud}(\%)) /([\mathrm{Hg}] /$ $\left.\operatorname{mud}_{\text {background }}(\%)\right)$. The $[\mathrm{Hg}] / \mathrm{mud}_{\text {background }}$ value was obtained from the media of ratios for 21 stations characterized as having natural mercury concentration, inside the $95 \%$ confidence band of extrapolation from the regression curve (Figure 6). Table 3 shows the mercury concentration and the calculated Enrichment Factors for $\mathrm{Hg}$. A value of $0.5 \leq \mathrm{EF} \leq 1.5$ suggests that traces of metal may be due to crustal materials or natural weathering processes. ${ }^{37}$ In estuarine stations $(6,9,10$, $11,12,13,14)$ and in mangrove stations $(18,21,23$, 24 ), which presented $E F>1.5$, there is evidence that an important proportion of traces metal is delivered from others sources, ${ }^{38}$ suggesting environmental contamination by mercury and corresponding to the most contaminated region of estuarine system. All these stations (except station 12) presented mercury concentrations above 5 times the TEL $\left(0.13 \mu \mathrm{g} \mathrm{g}^{-1}\right)$ or over the PEL $\left(0.70 \mu \mathrm{g} \mathrm{g}^{-1}\right)$. 
Table 3. Mercury concentration $\left(\mu \mathrm{g} \mathrm{g}^{-1}\right)$ and Enrichments Factor (EF)

\begin{tabular}{cccccc}
\hline Station & {$[\mathrm{Hg}]$} & $\mathrm{EF}$ & Station & {$[\mathrm{Hg}]$} & $\mathrm{EF}$ \\
\hline 1 & 0.15 & 0.5 & 17 & 0.24 & 1.4 \\
2 & 0.31 & 1.0 & $\mathbf{1 8}$ & 0.71 & $\mathbf{2 . 1}$ \\
3 & 0.04 & 0.3 & 19 & 0.34 & 1.1 \\
4 & 0.04 & 0.6 & 20 & 0.32 & 1.0 \\
5 & 0.47 & 1.3 & $\mathbf{2 1}$ & 0.67 & $\mathbf{2 . 1}$ \\
$\mathbf{6}$ & 1.03 & $\mathbf{2 . 8}$ & 22 & 0.15 & 0.8 \\
7 & 0.16 & 0.5 & $\mathbf{2 3}$ & 0.76 & $\mathbf{2 . 3}$ \\
8 & 0.26 & 1.3 & $\mathbf{2 4}$ & 0.76 & $\mathbf{3 . 0}$ \\
$\mathbf{9}$ & 0.71 & $\mathbf{2 . 3}$ & 25 & 0.38 & 1.4 \\
$\mathbf{1 0}$ & 0.82 & $\mathbf{2 . 7}$ & 26 & 0.32 & 0.9 \\
$\mathbf{1 1}$ & 1.14 & $\mathbf{3 . 2}$ & 27 & 0.16 & 0.7 \\
$\mathbf{1 2}$ & 0.27 & $\mathbf{1 . 8}$ & 28 & 0.18 & 0.9 \\
$\mathbf{1 3}$ & 1.19 & $\mathbf{3 . 3}$ & 29 & 0.31 & 1.0 \\
$\mathbf{1 4}$ & 0.89 & $\mathbf{2 . 4}$ & 30 & 0.21 & 0.7 \\
15 & 0.34 & 0.9 & 31 & 0.41 & 1.2 \\
$\mathbf{1 6}$ & 0.05 & $\mathbf{1 . 8}$ & & & \\
\hline
\end{tabular}

$\overline{\text { Station with EF }>1.5 \text { are presented in bold, suggesting mercury }}$ contamination.

Since the analyzed data were relatively homogeneous in relation to the grain size charac-teristics, it is reasonable to believe that an initial separation of the samples into two sedimentological groups (samples with over and under $80 \%$ mud content) is sufficient to minimize the interference of grain size in the mercury concentrations. This is another procedure to identify mercury enrichment sites. We therefore expect that among the estuary sediments, some samples (with $<80 \%$ of mud) will present lower mercury concentrations than the other ones, except in the case of proximity of metal sources. As the same, all samples with > $80 \%$ of mud would consequently present higher mercury levels. A significant rise inside this group can be interpreted as due to mercury artificial enrichment. Considering the average mercury concentration for each group and its respective standard deviation as an indicator of the "normal" limit of the mercury distribution in the area under consideration, it is possible to identify values related to anomalous input (e.g., outside the mean range).

As presented in Table 4, four estuarine samples 8, 11, 12 and 13 (Figure 2) and four mangrove sediment samples 18, 21, 23 and 24 (Figure 3), have shown concentrations

Table 4. An indicator of the "normal" limit of the mercury distribution in the study area (It is possible to identify values related to anomalous input e.g., outside of the mean range)

\begin{tabular}{ccccc}
\hline & Group & Samples & Mean \pm SD & $\begin{array}{c}\text { Samples Out } \\
\text { of Range }\end{array}$ \\
\hline Estuary & $\mathrm{A}(<80 \%$ mud $)$ & $1,3,4,8,12,16$ & $0.14 \pm 0.11$ & 8 and 12 \\
& $\mathrm{~B}(>80 \%$ mud $)$ & $2,5,6,7,9,10$, & $0.71 \pm 0.37$ & 11 and 13 \\
& & $11,13,14,15$ & \\
Mangrove & $\mathrm{C}(<80 \%$ mud $)$ & $17,22,24$, & $0.31 \pm 0.24$ & 24 \\
& & $25,27,28$ \\
& $\mathrm{D}(>80 \%$ mud $)$ & $18,19,20,21,23$, & $0.45 \pm 0.21$ & 18,21 and 23 \\
& & $26,29,30,31$ & & \\
\hline
\end{tabular}

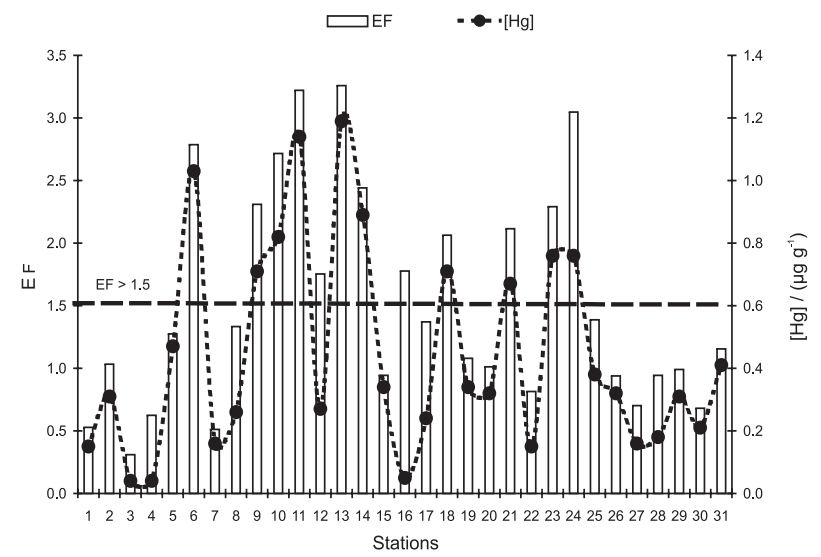

Figure 7. EF versus the distribution of $\mathrm{Hg}_{\text {Total }}$ in sediment samples of the estuarine collected near the submarine outflow (stations: 1, 2, 3 and 4, Santos Bay); along the Harbor Channel (stations: 5, 6, and 7); the area under heavily industrial influence (stations: 8, 9, 10, 11 and 12. Piaçaguera Channel); along Largo da Pompeba (stations: 13, 14, 15 and 16, São Vicente Estuary) and sediment sampled along the mangrove area (stations: $17-31$ ).

above the highest determined limit for their groups. All these samples are from the nearby area, under strong influence of Cubatão Industrial complex and the polluted solid wastes disposal sites (Figure 1).

\section{Mercury versus socioeconomic activities}

The samples mentioned above are undoubtedly the most critical in relation to the accumulation of mercury in the sediments, according to statistical analysis studies and normalization of data. But the spatial distribution of this metal versus $\mathrm{EF}$, in the respective socioeconomic activities in the neighborhood of the sampling sites (Figure 7), supported the suggestion for an analysis of the anthropogenic influence in the estuarine system.

Influence of the industrial activities upon the city of Cubatão, mostly petro-chemical and fertilizer industries and the polluted dredged sediment disposal sites along the Piaçaguera Channel (the head of the estuarine system) is represented mainly by stations 9, 10 and 11 (Figures 1, 2 and 7). A rise in the mercury concentration was evident, because all these samples presented a high $\mathrm{EF}(>2)$ and a mercury concentration above the $P E L$, confirming mercury contamination in that region. A clear dilution was observed in the neighboring area (stations 8 and 12), but nevertheless concentrations were maintained twice above the TEL limit. However, when the mud content normalization by Enrichment Factor $(\mathrm{EF}=1.8)$ was analyzed in station 12 (Table 3), environmental contamination by mercury was shown, near the most polluted stations. The mercury reduction at that point could be a consequence of the mud content reduction, since the mud content is higher at points 13 and 14 , and so are the mercury concentrations. 
Supposedly, stations 12, 13 and 14 with EF > 1.5, are also subject to the large impact from industrial effluents, irregular industrial waste disposal beside the impact of the domestic waste disposal nearby the Largo da Pombeba. In this case, it was observed that the normalization by EF (Table 3) was better than extrapolation from the regression curve normalization (Figure 6), where the station 12 is inside the $95 \%$ confidence band and can be characterized as having a natural mercury concentration.

A clear dilution of mercury concentration could be observed in the station 15 (downstream $7 \mathrm{~km}$ to the Largo da Pombeba) and close to the mouth of this estuary (station 16). Near the Santos Bay, the sediments can be considered clean. It was observed that the normalization by extrapolation from the regression curve, where the station 16 is inside the $95 \%$ confidence band and can be characterized as having natural mercury concentration was better than the EF normalization $(\mathrm{EF}>1.5)$, indicating mercury contamination nearby the most polluted stations. This distortion was caused by the low mud content presented by the station 16 .

Harbor activities in the Santos Estuary may be regarded as another important mercury source, and their influence acts primarily over the stations 5, 6, 7 and 8 (Figures 2 and $7)$. The increase of mercury levels was evident in the station 6 , central area of the port $(\mathrm{EF}=2.8)$. Lower mercury concentrations, $\mathrm{EF}<1.5$, but still above the limit established for clean marine sediments, occur upstream (stations 7 and 8) and downstream $6 \mathrm{~km}$ (station 5). This last station was near the edge of the harbor channel, where dredging does not usually occur. In a depth of $4 \mathrm{~m}$, the mercury concentration was $0.47 \mu \mathrm{g} \mathrm{g}^{-1}$, which is a significant increase in mercury concentrations in relation to clean sediments (about three times over the TEL). However, another station sampled by Abessa, ${ }^{31}$ to a depth of $10 \mathrm{~m}$, in the area revolved by dredging, nearer the station 5 but not near the edge, the mercury concentration was $0.12 \mu \mathrm{g} \mathrm{g}^{-1}$, lower than TEL. These data demonstrate that contaminated sediments have been removed from the harbor channel. ${ }^{39}$

The mercury concentration found in the group of sediments from the Santos Bay was examined in relation to the EF (Figure 7). It was verified that all samples presented $\mathrm{EF}<1.5$, suggesting a natural concentration of mercury in that area, where the Santos submarine outflow discharges in a high hydrodynamic circulation area and the dilution effect can improve the general environmental conditions of this area. However, a slight increase of the mercury concentrations was observed in the proximity of the outlet (such as stations 2 and 1 (Fig. 1), in which the mercury concentrations were above or slightly above the TEL). Only in stations 3 and 4, located relatively far from the sewage emissions outlet $(4.5 \mathrm{~km})$, presented mercury concentration below the TEL limit $\left(0.13 \mu \mathrm{g} \mathrm{g}^{-1}\right)$, when no adverse effect occurs in the biological community, and the sediment can be considered clean, as indicated in Figure 2.

All the mangrove sediment samples (Figure 3) were above the TEL limit, but only about $25 \%$ of these (stations 18, 21, 23 and 24) presented EF > 1.5 and were near or above PEL limit. These stations, are located in an area under strong impact caused by industrial activity, including chemical effluents from a chloro-alkali plant with contaminated soils, in which mercury cathode was used in the production line (Figure 1). This area is located in the inner portion of an intricate system of fluvial drainage, due to its proximity to several sources of chemical pollutants and restrict exchanges with marine waters.

\section{Conclusions}

In most stations the measured levels of mercury were above $0.13 \mu \mathrm{g} \mathrm{g}^{-1}$ (TEL), which indicates contamination according to the Canadian legislation ${ }^{33}$ limit, adopted by CETESB,${ }^{14}$ whereas below that no adverse effect in the biological community is observed.

The utilization of two normalization techniques of mercury with mud content can be used as complementary techniques to minimize the disadvantages of each procedure, and the granulometric normalization technique was confirmed as a method that can detect the degree of mercury contamination of the studied area. In general terms, the most critical areas concerning mercury accumulation are the estuarine channels under the influence of the Cubatão Industrial Complex, mostly petro-chemical and fertilizer industries that present areas with contaminated soils, irregular industrial wastes disposal and liquid effluents release along the Piaçaguera Channel (the head of the system), where it is also observed the presence of polluted dredged sediments disposal sites (Figure 1).

Accumulation was also verified in the neighborhood of the cities of Santos and São Vicente, area influenced by domestic waste disposal. This area is located at the northern edge of the São Vicente Island, between Largo da Pompeba (in the São Vicente Estuary) and the end of the Piaçaguera Channel (in the Santos Estuary). Besides the presence of these important metal sources, this region is also affected by tides restricting water circulation, what hinders the dispersion of the contaminants present in sediments. Mercury contamination is diluted downstream the estuary and reaches the lowest levels in the Santos Bay. Nevertheless, along the estuarine axis some abnormalities in the general pattern were found, probably in function of additional contaminant sources, such as the port, and waste disposal areas. 
The results presented demonstrate that mercury pollution is still a problem for the bent ecosystem of Santos - São Vicente Estuarine System, although the levels of metals in water apparently decreased over recent years, according to some studies made by the environmental control agency of São Paulo State (CETESB).${ }^{14}$ The serious damage caused by mercury is sufficiently known to justify a strong environmental policy for the Baixada Santista to reduce and eventually eliminate the use of this metal in technological processes.

\section{Acknowledgments}

The authors thank to FAPESP for partial support of this research (Project Number 95/06655-9). We also thank to Dr. Michel M. de Mahiques and to Marcelo Rodrigues (MSc), for their help with the organic compounds analysis.

\section{References}

1. Giordano, R.; Lombardi, G.; Ciaralli, L.; Becallloni, L.; Sepe, A.; Ciprotti, M.; Constantini, S.; Sci. Total Environ. 1999, 227, 29.

2. Harland, B. J.; Taylor, D.; Wither, A.; Sci. Total Envviron. 2000, 253, 45.

3. Schintu, M.; Degetto, S.; Sci. Total Envviron. 1999, 241, 129.

4. Pereira, M. E.; Duarte, A. C.; Millward, G.E.; Abreu, S. N.; Vale, C.; Wat. Sci. Tech. 1998, 37, 125.

5. Fontaine, T. A.; Moore, T.D.; Burgoa, B.; Wat. Res. 2000, 34, 3473.

6. Szava-Kovats, R.C.; Appl. Geochem. 2002, 17, 1149.

7. Rodríguez Martín-Doimeadios, R. C.; Tessier, E.; Amouroux, D.; Guyoneaud, R.; Mar. Chem. 2004, 90, 107.

8. Bisinoti, M.C.; Jardim, W.F.; Quim. Nova, 2004, 27, 593.

9. Malm, O.; Branches, F.J.P.; Akagi, H.; Castro, M.B.; Pfeiffer, W.C.; Harada, M.; Bastos, W.R.; Kato, H.; Sci. Total Environ. 1995, 175, 127.

10. Palheta, D.; Taylor, A.; Sci. Total Environ. 1995, 168, 63.

11. Cai, Y.; Bayona, J.M.; J. Chromatogr. A 1995, 696, 113.

12. May, K.; Stoeppler, M.; Reising, K.; Toxicol. Environ. Chem. 1987, 13, 153.

13. Harari, J.; Mesquita, A. R.; Marone, E.; França, C. A. S.; Camargo, R.; Pereira, J. E. R.; Adão, C. J. G. P.; Sá Junior, I. L.; Technical Report of the Project: Flow Measurements in the Bay of Santos, FUNDESPA, São Paulo, 1990.

14. CETESB, institutional author; Sistema Estuarino de Santos São Vicente, Relatório Técnico, São Paulo/SP, Brasil, 2001.

15. Bolivar, J.P.; Garcia-Tenorio, R.; Ma, J.L.; Vaca, F.; Environ. Int. 2002, 27, 639.

16. Tommasi, L.R.; Honorate Professor Thesis, Instituto Oceanográfico, Universidade de São Paulo, São Paulo, 1979.
17. CETESB, institutional author; Metais Pesados na Baía de Santos e Estuário de Santos São Vicente, 1981.

18. CETESB, institutional author; Contaminantes na Bacia do Rio Cubatão e seus Reflexos na Biota Aquática, Arquivo Técnico, São Paulo/SP, Brasil, 1990.

19. Prósperi, V.; Eysink, G.G.J.; Saito, L.M.; Relatório Técnico, CETESB, São Paulo/SP, Brasil, 2001.

20. Akagi, H.; Malm, O.; Kingo, Y.; Harada, M.; Branches, F.J.P.; Pfeifer, W.C.; Kato, H.; Sci. Total Envviron. 1995, 175, 85.

21. Fostier, A.H.; Ferreira, J.R.; Deandrade, M.O.; Quím. Nova. 1995, 18, 425.

22. Martinez-García, M. L.; Carlosena, A.; Lopez-Mahía, P.; Muniategui, S.; Prada, D.; Analusis 1999, 27, 61.

23. Instituto Nacional de Metrologia, Normalização e Qualidade Industrial (INMETRO); Orientações sobre Validação de Métodos de Ensaios Químicos, DOQ-CGCRE-008, 2003.

24. Flemming, B.W.; Continental Shelf Research. 2000, 20, 1125.

25. Gross, M.G. In Procedure in Sedimentary Petrology; Carver, R.E., ed.; Wiley-Interscience: New York, 1971, ch. 25.

26. Bonetti, C.V.D.H.; Ph.D. Thesis, Universidade de São Paulo, Instituto Oceanográfico, São Paulo, 2000.

27. Mahiques, M. M.; Honorate Professor Thesis, Instituto Oceanográfico, Universidade de São Paulo, São Paulo, 1998.

28. Zar, J.H.; Biostatistical Analysis, $3^{\text {rd }}$ ed.; Prentice-Hall: NJ, USA, 1996.

29. Clark, M.W.; Davies-McConchie, F.; McConchie, D.; Birch, G.F.; Sci. Total Environ. 2000, 258, 149.

30. Aloupi, M.; Angelidis, M. O.; Environ. Pollut. 2001, 113, 211.

31. Abessa, D.M.S.; Ph.D. Thesis, Universidade de São Paulo, Instituto Oceanográfico, São Paulo, 2002.

32. Carvalho, R.E.; Cubatão e o Jornalismo Ecológico: Estudo de Três Momentos, CETESB, São Paulo/SP, 1994.

33. Environment Canada. Canadian Sediment Quality Guidelines for the Protection of Aquatic Life. Summary Tables. http:// www.ec.gc.ca, accessed in September 2004.

34. Gomes, A. de O.; Azevedo, D. de A.; J. Braz. Chem. Soc. 2003, 14, 358.

35. Fernandes, M.B.; Sicre, M.A.; Cardoso, J.N.; Macêdo, S.J.; Sci. Total Environ. 1999, 231, 1.

36. Loring, D.H.; Mar. Chem. 1990, 29, 155.

37. Zhang, J.; Liu, C.L.; Estuarine, Coastal and Shelf Science 2002, 54, 1051.

38. Feng, H.; Han, X.; Zhang, J.; Yu, L.; Mar. Pollut. Bull. 2004, 49, 910.

39. Hortellani, M. H.; MSc. Dissertation, Instituto de Pesquisas Energéticas e Nucleares, São Paulo, 2003.

Received: May 20, 2004 Published on the web: August 30, 2005

FAPESP helped in meeting the publication costs of this article. 